\title{
Endocrine disruptors: Analytical and toxicological aspects
}

ver the last 5 years, concerns have increased about chemicals in the environment, which influence the reproductive capabilities of human and animals. Reproductive hormone-receptor systems appear to be especially vulnerable. Hormonal disturbances in wildlife include sex changes in riverine fish and marine snails, reproductive failure in birds, genital tract malformations in mammals. These effects may be attributed to various classes of chemicals such as chlorinated pesticides (DDT, endrin, pentachlorophenol) or chlorinated aromatic compounds (PCBs, dioxins), metals (cadmium, selenium, zinc, mercury, tributyltin), alkylphenols (nonylphenol, pentylphenol, bisphenol), phytooestrogens. The identification of the chemicals responsible of these reproductive alterations is difficult and demands the development of specific procedures to analyse these compounds in complex environmental mixtures. Moreover the causal relationships between the exposure to these substances by wildlife organisms and the adverse effects on reproduction in the environment are not yet clear evidence.

C. Pellisseo-Bennetau (Enita, Gradignan, France) reviews in the first paper, the presence of phytooestrogens in the food diet both for human and also animals, with the influence on the health status. The paper of P. de Voogt and N. Jonkers (University of Amsterdam, Netherlands) is related to the development of combined analytical techniques for the determination of alkylphenol ethoxylates in sewage treatment plant samples and also in biological matrices (fish, mussels). M. Sole (CID/CSIC, Barcelona, Spain) presents the determination of the levels of nonylphenol ethoxylates in Spanish rivers (both water and fish samples) in conjunction with the detection of vitellogin in male carp plasma using a polyclonal antibody to check feminisation. E. Hill (University of Sussex, Brighton, UK) shows that alkylphenols may be retained in fish tissues over one week and that alkylphenol metabolites measured in biliary could be a useful marker of recent exposure to alkylphenols. In the relation with these works, J.P Cravedi (INRA, Toulouse, France) observed the metabolism of tritied 4-nonylphenol in trout, salmon exposed in the laboratory and also in rat/human hepatocytes and concluded to a rapid biotransformation of this chemical in vertebrates. C. Minier (Université du Havre, France) checking several physiological parameters, observed high levels of intersex fish in small rivers from north of France and also in flounders caught in the Seine estuary.

These papers are a selection of the oral communications presented at the "Club environment" of the "Cercle des Sciences Analytiques" during a one-day session dedicated to the Endocrine Disruptors (21 ${ }^{\text {st }}$ January 2000, INA-PG, Paris, France).

\section{References}

\author{
1. National Institute of Environmental Health Sciences: http://ntp-server.niehs.nih.gov \\ 2. OECD: http://oecd.org \\ 3. Environmental Protection Agency (US-EPA): http://www.epa.gov \\ 4. European Environmental Agency: http://eea.eu.int \\ 5. National Research Council Hormonally active agents in the environment; Washington D.C.: National Academy Press, 1999. \\ 6. Kime, D.E. Endocrine Disruption in Fish; London, UK: Kluwer Academic, 1998. \\ 7. Cadbury, D. The feminisation of Nature: our Future at Risk; London: Penguin Books Ltd., 1998. \\ 8. Colborn, T.; Dumanovski, D.; Myers, J.P. Our stolen Future; New York: Plume/Penguin, 1996. \\ 9. Maczka, C.; Pang, S.; Policansky, D.; Wedge, R. Env. Sci. Tech. 2000, 136A-140A. \\ 10. Colborn, T.; Vom Saal, F.S.; Soto, A.M. Environ. Health Perspect. 1993, 101, 378-384. \\ 11. Sumpter, J.P.; Jobling, S. Environ. Health Perspect. 1995, 103, 172-178.
}

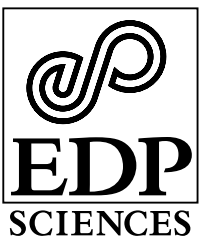

http://www.edpsciences.org 


\section{Endocrine disruptors: Analytical and toxicological aspects}

761 Foreword

Ph. Garrigues

763 Phytoestrogens, endocrine disrupters from food

C. Bennetau-Pelissero, K. Latonnelle, A. Séqueira and V. Lamothe

776 Alkylphenol ethoxylates and their degradation products in abiotic and biological samples from the environment

P. de Voogt, O. Kwast, R. Hendriks and N. Jonkers

783 Estrogenicity determination in carp, Cyprinus carpio: a laboratory and field approach M. Solé, M. Castillo, M.J. Lopez de Alda, C. Porte and D. Barceló

789 Bioconcentration and metabolism of 4-tert-octylphenol in roach (Rutilus rutilus) fry A.M.R. Ferreira-Leach and E.M. Hill

793 Identification of 4-n-nonylphenol metabolic pathways and residues in aquatic organisms by HPLC and LC-MS analyses

R. Thibaut, A. Jumel, L. Debrauwer, E. Rathahao, L. Lagadic and J.P. Cravedi

801 An investigation of the incidence of intersex fish in Seine-Maritime and Sussex region. C. Minier, G. Caltot, F. Leboulanger and E.M. Hill

Cover picture by C. Minier:

Hormonal disruption observed into the aquatic environment: section of gonad of a male gudgeon from the river Seine (France) showing primary oocytes within male tissue. Two oocytes exhibit respectively two and three nuclei. 